\title{
Numerical analysis of the Venda Nova II powerhouse complex
}

\author{
T. Miranda \& A. Gomes Correia \\ University of Minho, Department of Civil Engineering, Guimarães, Portugal \\ S. Eclaircy-Caudron \& D. Dias \\ INSA, Lyon, France \\ C. Lima \\ EDP-Produção, Porto, Portugal
}

L. Ribeiro e Sousa

University of Porto, Department of Civil Engineering, Porto, Portugal

\begin{abstract}
In the North of Portugal a hydroelectric scheme called Venda Nova II was recently built in order to optimize the resources of the reservoirs created by Venda Nova and Salamonde dams. The scheme, almost fully composed by underground structures and built in a predominantly granite rock mass, include several tunnels with a total length of about $7.5 \mathrm{~km}$, inclined and vertical shafts with a total length of $750 \mathrm{~m}$ and two caverns which compose the powerhouse complex. The complex consists of two caverns interconnected by two galleries at a dept of about $350 \mathrm{~m}$. For this complex, 2D and 3D numerical models were developed considering the different construction stages. The geomechanical parameters of the granite formation for the numerical models were obtained using GEOPAT. This software is a knowledge based system which allows obtaining geomechanical parameters for underground structures modelling in granite formations. The 2D model was developed in the Phases2 software while the 3D model in FLAC3D. In this paper results of these models are analysed. Some comparisons are carried out between the models results and the monitored data. The numerical results show in general a good agreement with the monitored ones.
\end{abstract}

\section{INTRODUCTION}

In the 90's the CPPE (Portuguese Company of Electricity Production) decided to reinforce the power of Venda Nova hydroelectric scheme by building a new one, named Venda Nova II, that took advantage of the high existing head - about $420 \mathrm{~m}$ - between two reservoirs (Lima et al., 2002; Plasencia, 2003). Venda Nova II is equipped with two reversible units in order to optimize the use of the water resources for energy production. It was built in a predominantly good quality granite rock mass and involved the construction of important geotechnical underground works of which the following can be mentioned:

- the access tunnel to the caverns, with about $1.5 \mathrm{~km}, 10.9 \%$ slope and $58 \mathrm{~m}^{2}$ cross-section;

- the hydraulic circuit with a $2.8 \mathrm{~km}$ headrace tunnel with $14.8 \%$ slope and a $1.4 \mathrm{~km}$ tailrace tunnel and $2.1 \%$ slope, with a $6.3 \mathrm{~m}$ diameter modified circular section;

- the powerhouse complex located at about $350 \mathrm{~m}$ depth with two caverns, for the powerhouse and transforming units, connected by two galleries;

- an upper surge chamber with a $5.0 \mathrm{~m}$ diameter and $415 \mathrm{~m}$ height shaft and a lower surge chamber with the same diameter and $60 \mathrm{~m}$ height.

Figure 1 shows a general perspective of the power reinforcement scheme. 


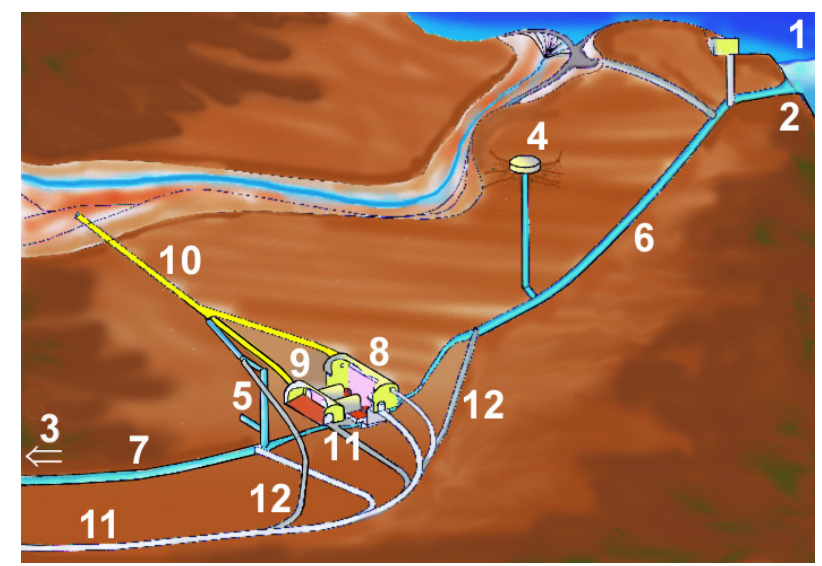
1 - Venda Nova reservoir
7 - Tailrace tunnel;
2 - Upper intake
8 - Powerhouse cavern
3 - Lower intake
9 - Transformer cavern
4 - Upper surge chamber
10 - Ventilation galleries
5 - Lower surge chamber
11 - Access tunnel
6 - Headrace tunnel
12 - Auxiliary tunnels

Figure 1. General perspective of the power reinforcement scheme (Lima et al., 2002)

\section{THE UNDERGROUND POWERHOUSE COMPLEX}

\subsection{Description}

The powerhouse complex, located in a intermediate position of the hydraulic circuit, was built at a depth of approximately $350 \mathrm{~m}$. It is composed by two caverns interconnected by two galleries (Figure 2). The dimensions of the main cavern are, in plan, 19.0x60.5m while for the transforming units cavern are $14.1 \times 39.8 \mathrm{~m}$. The distance between their axes is $45.0 \mathrm{~m}$.

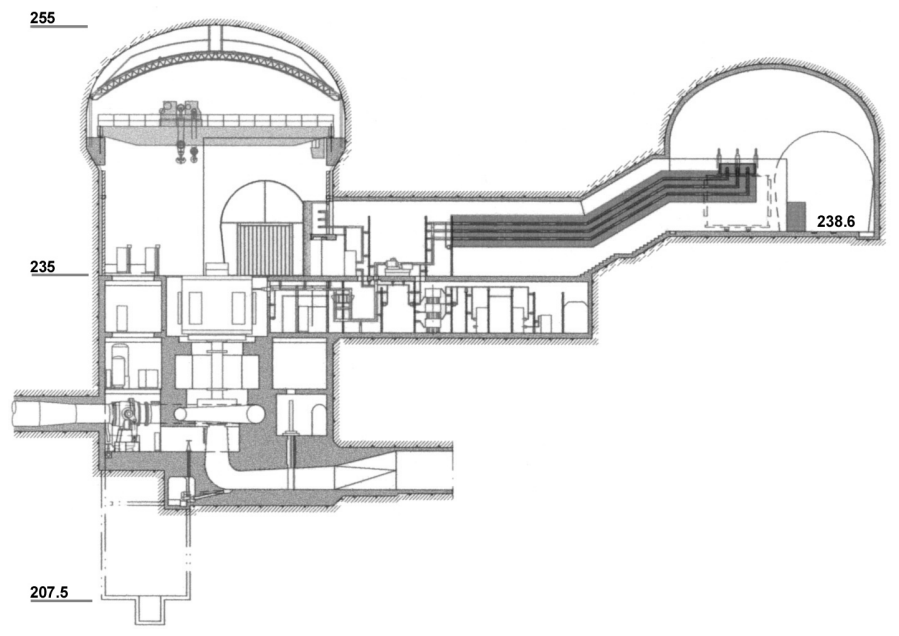

Figure 2. Powerhouse complex

The caverns are located in an area where the existence of two subvertical discontinuities was detected as shown in Figure 3. These discontinuities are identified as E and F. Based on the interpretation of the geotechnical survey results, it was decided to move the caverns in the NE direction. 


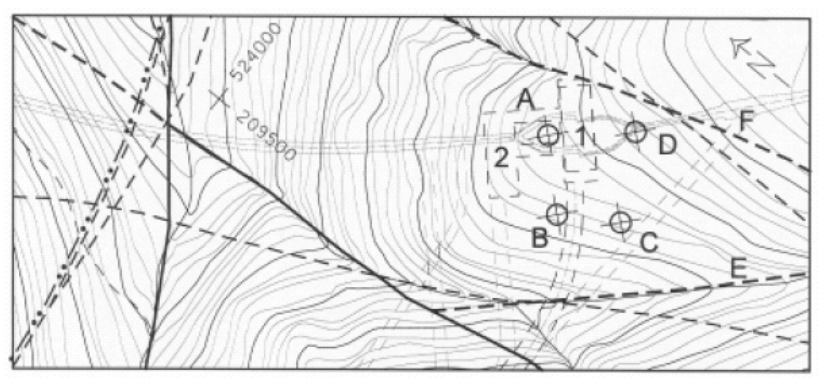

Figure 3. Implantation of the powerhouse complex

A coarse porphyritic, both biotitic and moscovitic, granite prevails in the region. The rock mass on which the hydroelectric complex is installed is characterized by medium-size grain granite of a porphyritic trend with quartz and/or pegmatitic veins and beds, which are occasionally, rose. The rock mass also presents embedment of fairly quartzitic mica-schist.

\subsection{Geotechnical survey and monitoring plan}

The complex was built in a granite rock mass with good geomechanical quality. To characterize the rock mass in the area of the caverns, four vertical boreholes with continued sample recovery were performed (Plasencia, 2003). The lengths of these boreholes varied between $271.0 \mathrm{~m}$ and $381.6 \mathrm{~m}$ and their positioning controlled each $50 \mathrm{~m}$. A total of 98 samples were collected. The laboratory tests performed in these samples allowed the zoning of the rock mass as presented in Table 1. Caverns are located in the ZG1C zone. Lugeon permeability tests were also executed.

Table 1. Geological-geotechnical zoning of the rock mass

\begin{tabular}{|l|l|l|l|l|l|l|l|}
\hline & Weathering & Disc. & RQD & Perm. & $\mathrm{I}_{\mathrm{r}}(\mathrm{MPa})$ & $\mathrm{UCS}(\mathrm{MPa})$ & $\mathrm{E}_{\mathrm{r}}(\mathrm{GPa})$ \\
\hline ZG3C & W3/W4-5 & F3/F4-5 & $0-90$ & $>10 \mathrm{UL}$ & 3.8 & 57.7 & 42.0 \\
\hline ZG2C & W1-2/W3 & F1-2/F3 & $50-90$ & $0-8 \mathrm{UL}$ & 6.3 & 96.9 & 51.0 \\
\hline ZG1C & W1/W2 & F1/F2 & $90-100$ & <2 UL & 7.0 & 110.1 & 54.9 \\
\hline
\end{tabular}

UL - Lugeon units; $E_{r}$ - deformability modulus of the intact rock; $I_{r}$ - Point load index; UCS - Uniaxial compressive strength

Between boreholes, seismic tests using longitudinal waves (P waves) were performed in order to obtain tomographies of the rock mass and to detect important geological structures (LNEC, 1997; Plasencia et al., 2000). These tests were executed at depths varying between 95 and 370m and the results confirmed the previous zoning. The area where the caverns are located was characterized with $P$ waves velocities between 5250 and $6000 \mathrm{~m} / \mathrm{s}$, sometimes 4750 to $5250 \mathrm{~m} / \mathrm{s}$. These values confirmed the good geomechanical characteristics of the rock mass.

After the construction of the access tunnel to the caverns a gallery was excavated in order to characterize the rock mass and confirm the previous geomechanical characterization and to measure the in situ state of stress. This gallery was excavated from the top of the access tunnel and parallel to the caverns axis. Large Flat Jack tests were used to obtain the deformability modulus of the rock mass. The values ranged from 33 to 40GPa. Strain Tensor Tube and Small Flat Jack tests were carried out for the stress state determination. The results showed that the vertical and horizontal stress parallel to the caverns axis have the same magnitude and correspond to the overburden dead load. In the perpendicular direction the stress values are 2 to 3 times higher $\left(\mathrm{K}_{0}\right.$ value between 2 and 3$)$. From the litological characterization it was possible to identify four main discontinuities sets. In Table 2 their main characteristics according to the ISRM (1978) criteria are summarized.

To evaluate the displacements in the rock mass surrounding the caverns, a monitoring plan using extensometers and convergence marks was established. The extensometers, in a total number of eleven, were placed in two sections and have lengths varying from $5 \mathrm{~m}$ to $40 \mathrm{~m}$ (Figure 4). The convergence marks were installed in several sections (5 to 7 each section). The three-dimensional convergence measurements readings were carried out using an optical system based on the total station technology. Six load cells were also installed for the anchors. Figure 5 shows the evolution of the measured displacements in the extensometers EF5 and EF11. 
Table 2. Characteristics of the four main families of discontinuities (Plasencia, 2003)

\begin{tabular}{|c|c|c|c|c|}
\hline Family & 1 & 2 & 3 & 4 \\
\hline Direction & $\mathrm{N} 81^{\circ} \mathrm{E}$ & N47W & N8E & N50E \\
\hline Inclination & $77 \mathrm{NW}$ & $12 \mathrm{NE}$ & $83 \mathrm{NW}$ & $80 \mathrm{NW}$ \\
\hline Continuity & 1 to $3 \mathrm{~m}$ & 1 to $10 \mathrm{~m}$ & 3 to $10 \mathrm{~m}$ & $3 \mathrm{~m}$ \\
\hline Alteration & $\begin{array}{l}\text { W1-2, occasion- } \\
\text { ally W3 }\end{array}$ & W1-2 & $\begin{array}{l}\text { W1-2, occasion- } \\
\text { ally W4 }\end{array}$ & W1-2 \\
\hline Opening & closed at $0.5 \mathrm{~mm}$ & closed at $0.5 \mathrm{~mm}$ & $\begin{array}{l}\text { closed at } 0.5 \mathrm{~mm} \text {, } \\
\text { sometimes } 2.5 \mathrm{~mm}\end{array}$ & closed \\
\hline Thickness & none at $0.5 \mathrm{~mm}$ & none at $0.5 \mathrm{~mm}$ & $\begin{array}{l}\text { none, sometimes } \\
2.5 \mathrm{~mm}\end{array}$ & none \\
\hline Roughness & $\begin{array}{l}\text { undulating poorly } \\
\text { rough to rough }\end{array}$ & $\begin{array}{l}\text { Undulating poorly } \\
\text { rough, sometimes } \\
\text { rough stepped }\end{array}$ & $\begin{array}{l}\text { rough plane, } \\
\text { sometimes pol- } \\
\text { ished }\end{array}$ & $\begin{array}{l}\text { undulating poorly } \\
\text { rough }\end{array}$ \\
\hline Seepage & Dry & Dry & $\begin{array}{l}\text { Dry, occasionally } \\
\text { with continuous } \\
\text { water flow }\end{array}$ & Dry \\
\hline Spacing & $\begin{array}{l}2 \text { to } 3 \mathrm{~m} \text {, some- } \\
\text { times } 1 \text { or } 4 \mathrm{~m}\end{array}$ & $\begin{array}{l}2 \text { to } 3 \mathrm{~m} \text {, some- } \\
\text { times } 1 \mathrm{~m}\end{array}$ & 1 to $2 \mathrm{~m}$ & 5 to $6 \mathrm{~m}$ \\
\hline
\end{tabular}

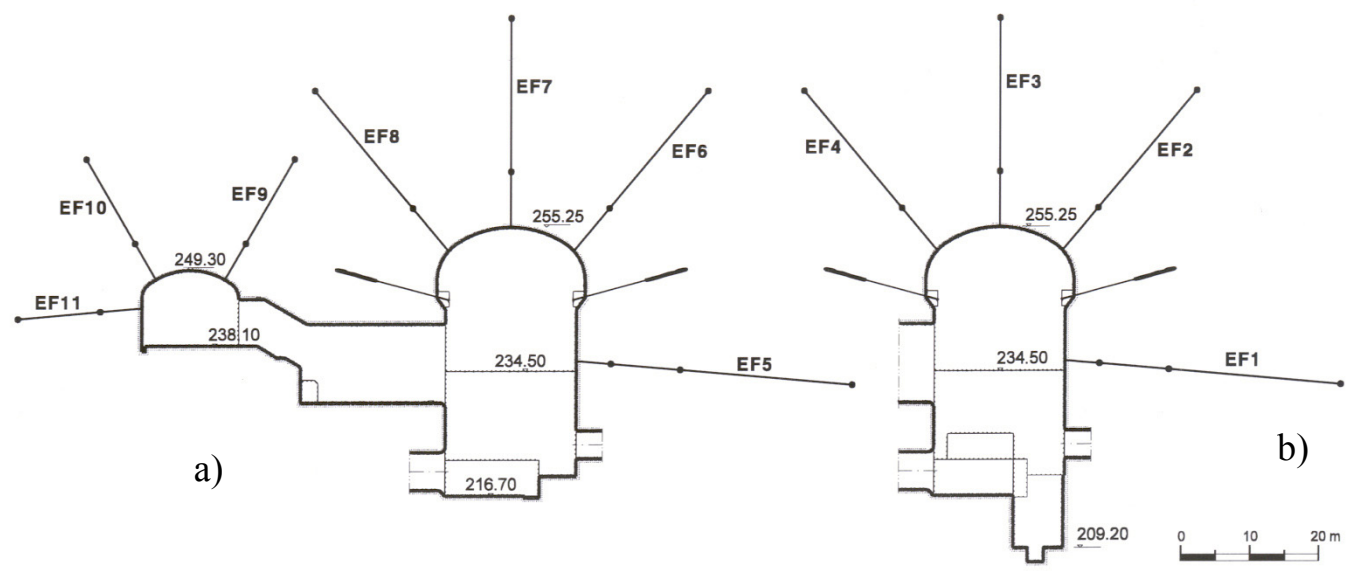

Figure 4. Cross-sections of the monitoring plan

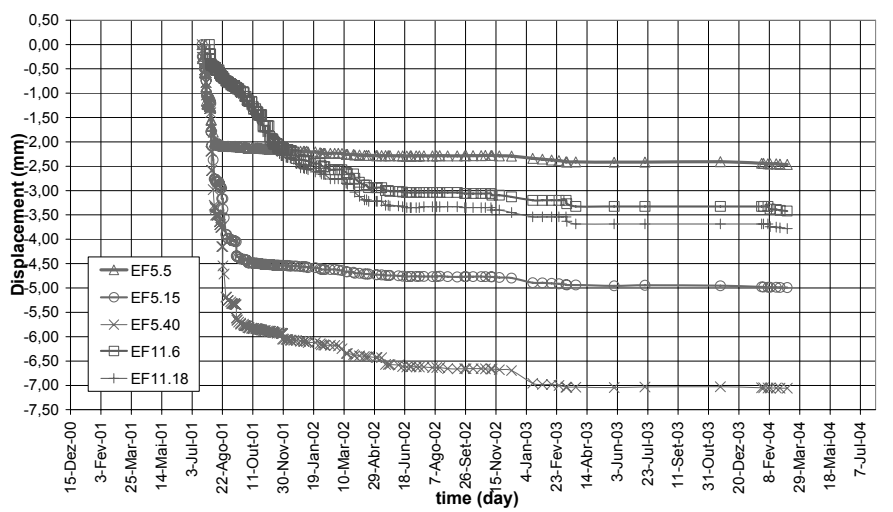

Figure 5. Evolution of displacements in extensometers EF5 and EF11

For the numerical models developed in this work, the geomechanical parameters were obtained using GEOPAT which is a Knowledge Based System especially developed at University of Minho for this purpose (Miranda, 2003). It uses well organized and structured knowledge from experts together with artificial intelligence techniques for decision support in the geomechanical parameters calculation and has been used with success in different applications. Using the gathered geotechnical information together with GEOPAT the following geomechanical parameters were obtained: deformability modulus $\mathrm{E}=45 \mathrm{GPa}$, friction angle $\phi^{\prime}=54^{\circ}$ and cohesion $\mathrm{c}^{\prime}=4 \mathrm{MPa}$. 


\section{NUMERICAL MODELLING}

The 3D model was developed using the finite difference software FLAC3D to simulate the complex geometry of the powerhouse complex and its construction sequence. It is composed by 43930 zones, 46715 grid-points and 1100 structural elements (Figure 6). Since the filed stress around the caverns was constant it was possible to simplify the mesh in order to be computationally more efficient. This way instead of the real $350 \mathrm{~m}$ depth of the cavern axis only $200 \mathrm{~m}$ was modelled.

The section analysed through the 2D numerical modelling was section a) referred in Figure 4. When comparisons between the two models are performed they are always referred to the results obtained for this cross-section where reliable monitoring values are available.

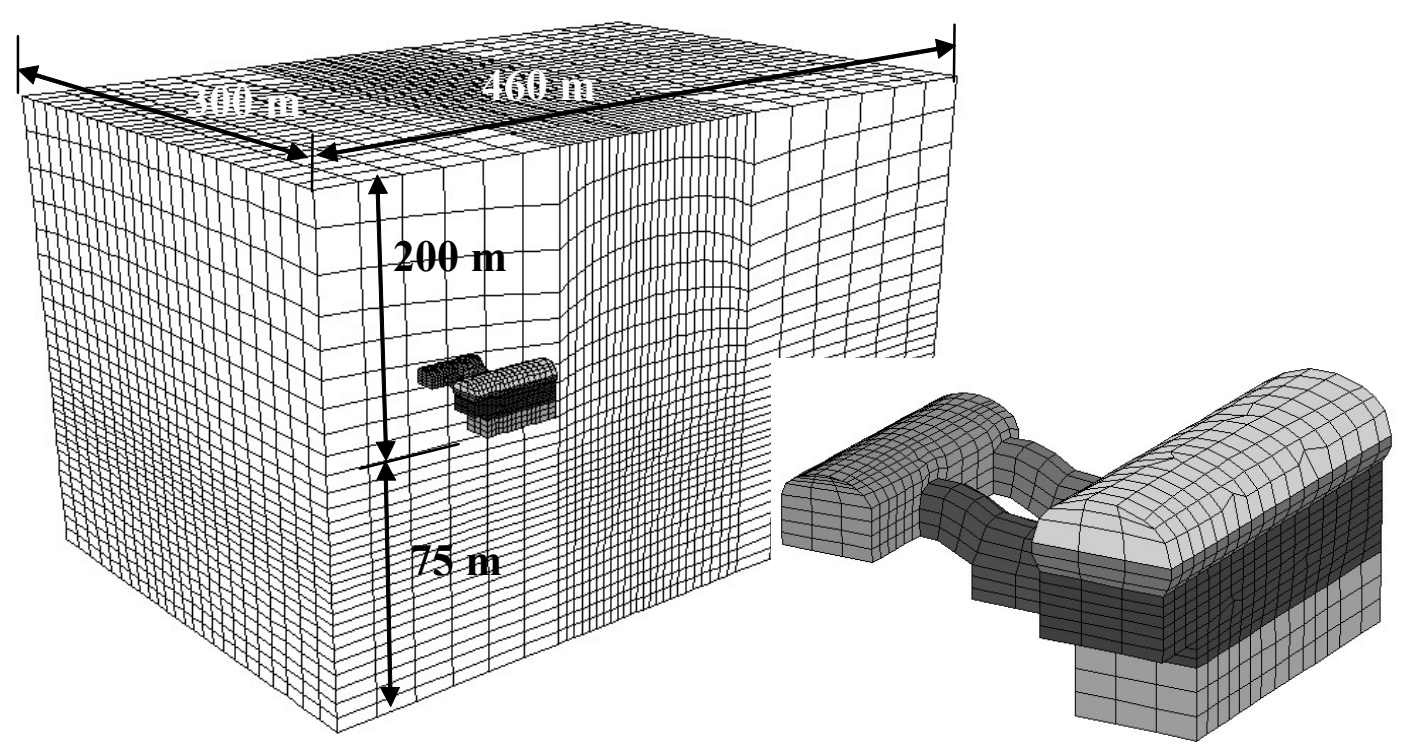

Figure 6. The 3D mesh.

The sprayed concrete was simulated by shell elements with a linear elastic and isotropic constitutive model, with a Young modulus of $15 \mathrm{GPa}$ and a Poisson ratio of 0.2. The rock bolts were simulated by cable elements which can yield tensile strength with two nodes and one axial degree of freedom.

For the numerical modelling, the construction sequence was simplified relatively to those defined in design. Therefore, the adopted stages are the ones presented in Table 3.

The construction sequence adopted for the 2D modelling was very similar. The only difference was the way the two interconnecting galleries were simulated. Three different approaches were carried out in a preliminary analysis: i) considering the total excavation of the galleries; ii) non considering the effect of the galleries excavation due to their small influence in the global behaviour of the structure; iii) replacing the material in the area of the galleries for another with lower equivalent geomechanical properties. The first approach led to unrealistic results with multiple shearing zones and high displacement levels which were not observed in the field. Since the model was developed considering plain strain conditions this consideration was too unfavourable. The remaining two approaches showed very similar results. The differences were insignificant therefore it was chosen not to consider the effect of the interconnecting galleries excavation in the following analysis.

The in situ tests pointed out for a $\mathrm{K}_{0}$ coefficient between 2 and 3 . For this analysis a starting value of 2 was considered. Due to the high $\mathrm{K}_{0}$ ratio and the span of the main cavern vertical wall, the higher displacements are expected to take place in that area. Figure 7 presents the displacements contours along with the corresponding vectors for the two models in the referred cross-section. It is possible to observe the same qualitative displacement patterns in both models. The displacement vectors show the strong influence of the high horizontal stress translated by higher displacements in the vertical walls of the main cavern. 
Table 3. Adopted construction stages for the 3D numerical model

\begin{tabular}{|c|c|c|}
\hline Stage & Model & Description \\
\hline 1 & & $\begin{array}{l}\text { Excavation of the upper part of the main cavern arch. Appli- } \\
\text { cation of } 25 \mathrm{~cm} \text { of fiber sprayed concrete on the arch and } 6 \mathrm{~m} \\
\text { length and } 25 \mathrm{~mm} \text { diameter rockbolts in a } 2 \times 2 \mathrm{~m} \text { mesh. }\end{array}$ \\
\hline 2 & & Excavation of the remaining main cavern arch. \\
\hline 3 & & $\begin{array}{l}\text { Excavation of the main cavern until the base level of the in- } \\
\text { terconnecting galleries and the transforming units caverns. } \\
\text { Application of } 25 \mathrm{~cm} \text { of fiber sprayed concrete on the arch of } \\
\text { the second cavern and } 6 \mathrm{~m} \text { length and } 25 \mathrm{~mm} \text { diameter rock- } \\
\text { bolts in a } 2 \times 2 \mathrm{~m} \text { mesh. }\end{array}$ \\
\hline 4 & & $\begin{array}{l}\text { Excavation of the two interconnecting galleries and applica- } \\
\text { tion of } 25 \mathrm{~cm} \text { of fiber sprayed concrete in the roof of the gal- } \\
\text { leries. }\end{array}$ \\
\hline 5 & & Completion of the main cavern excavation. \\
\hline
\end{tabular}
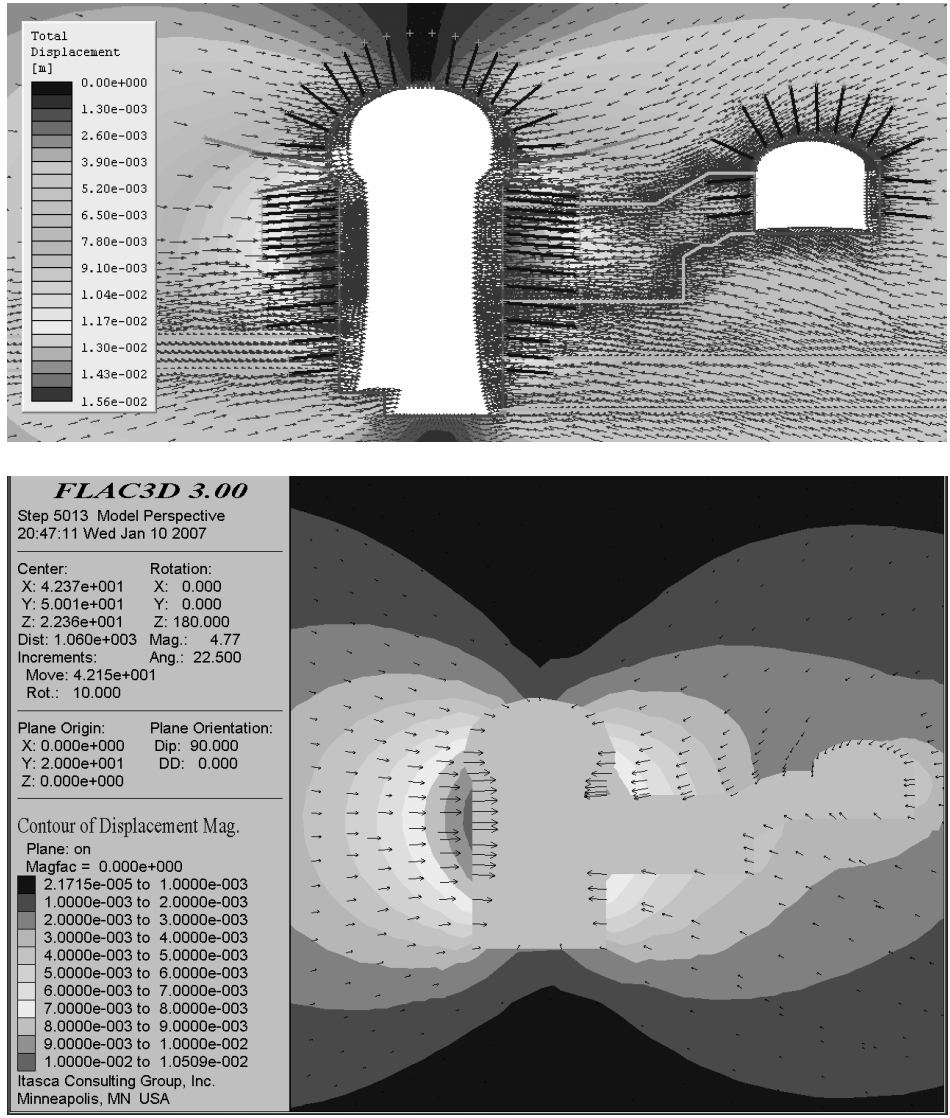

Figure 7. Displacement contours and vectors for the 2D (upper image) and 3D models 
For a more thorough analysis Figure 8 shows the computed displacements along lines coinciding with extensometers 5 and 7 (near the wall and roof of the main cavern, respectively). The displacements of the 2D calculation along the sub-horizontal line are much higher than for the 3D model which was expected due to the plain strain consideration. For the 3D model the maximum displacement along this line is approximately $10 \mathrm{~mm}$ while for the $2 \mathrm{D}$ model is almost $50 \%$ higher. The displacements near the ceiling of the main cavern are small for the two models. In this zone the gravity loads, which would cause a downward movement, are almost compensated with the high horizontal stress which pushes the arch upwards causing a near-zero displacement.
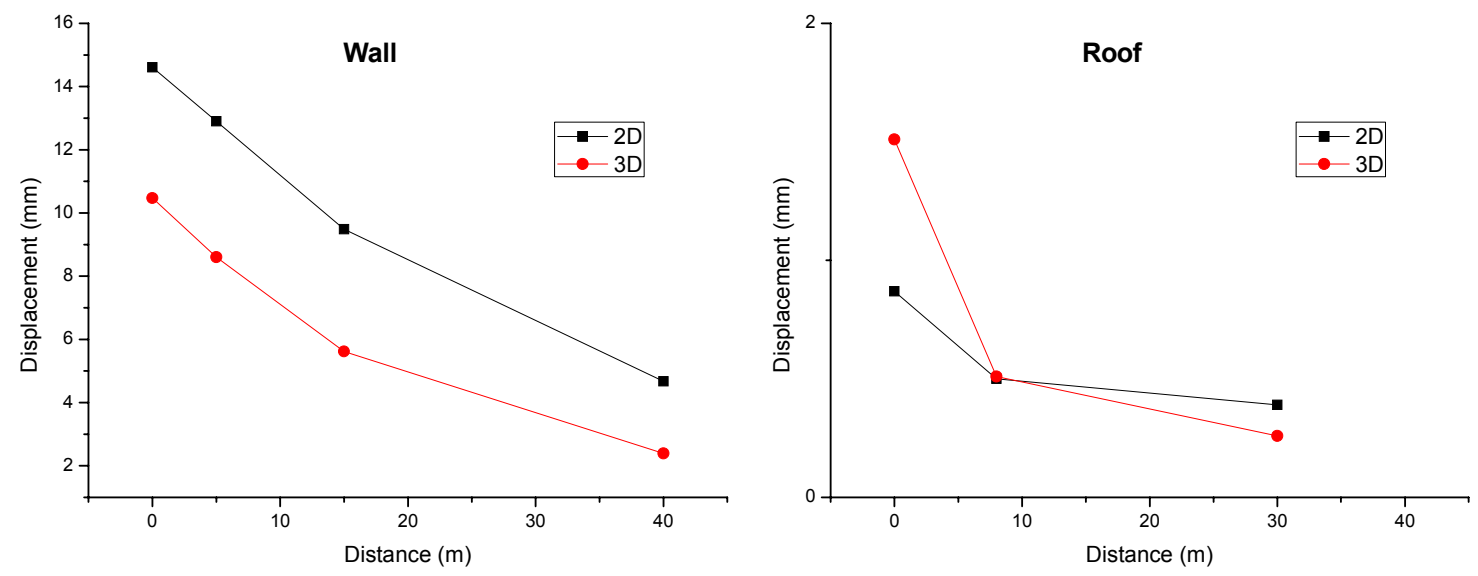

Figure 8. Computed displacement near the wall and roof of the main cavern

Due to the good overall quality of the rock mass the displacements magnitude is small. The maximum computed displacements in the rock mass are $15 \mathrm{~cm}$ for the $2 \mathrm{D}$ model and $10.5 \mathrm{~cm}$ for the $3 \mathrm{D}$ case. Moreover, there are a small number of yielded zones which are confined to small areas near the arch and wall of the main cavern.

The behaviour of the structure and surrounding rock mass is almost elastic. This means that the most important parameters for the behaviour prediction of the structure are $\mathrm{E}$ and $\mathrm{K}_{0}$. Also, the maximum computed shear strains were low with values ranging from $0.02 \%$ and $0.1 \%$ for the $2 \mathrm{D}$ model and $0.015 \%$ and $0.04 \%$ for the $3 \mathrm{D}$ model. Once more lower values were obtained for the 3D model. These values are within the expected range considering the quality of the rock mass and the construction method which caused very low damage to the rock mass.

Figure 9 compares the results of the models with the measures of extensometers 5 to 11 . The results of the 2D and 3D models are very similar for most of extensometers. Also, the computed values follow the same qualitative trend as the observed ones. The worst results are observed for the inclined extensometers of the main cavern (6 and 8) where the displacement values are clearly overestimated. In the remaining cases the $3 \mathrm{D}$ model is more accurate for the measurements of extensometers 5, 7 and 9 while the 2D model slightly outperforms the 3D model for extensometers 10 and 11. In a qualitative perspective it can be concluded that, excepting for extensometers 6 and 8 , the results of the models are very acceptable.

For a more thorough insight of the results, some statistical analysis was carried out. Tests were performed to the mean values of the measured and computed values in the extensometers and they can be considered statistically identical. The mean computed displacement is $2.47 \mathrm{~mm}$ (equal for both models) and the measured is $2.34 \mathrm{~mm}$.

The Shapiro-Wilk normality test was performed to the error values of the models. It was verified that they follow a normal distribution for a 95\% significance level. This fact suggests a good distribution of the errors with a mean value near $0(\approx 0.14 \mathrm{~mm})$ and points out for the good quality of the results. Also, a Smirnov test was performed and it was concluded that the observed and the computed values follow the same statistical distribution. 


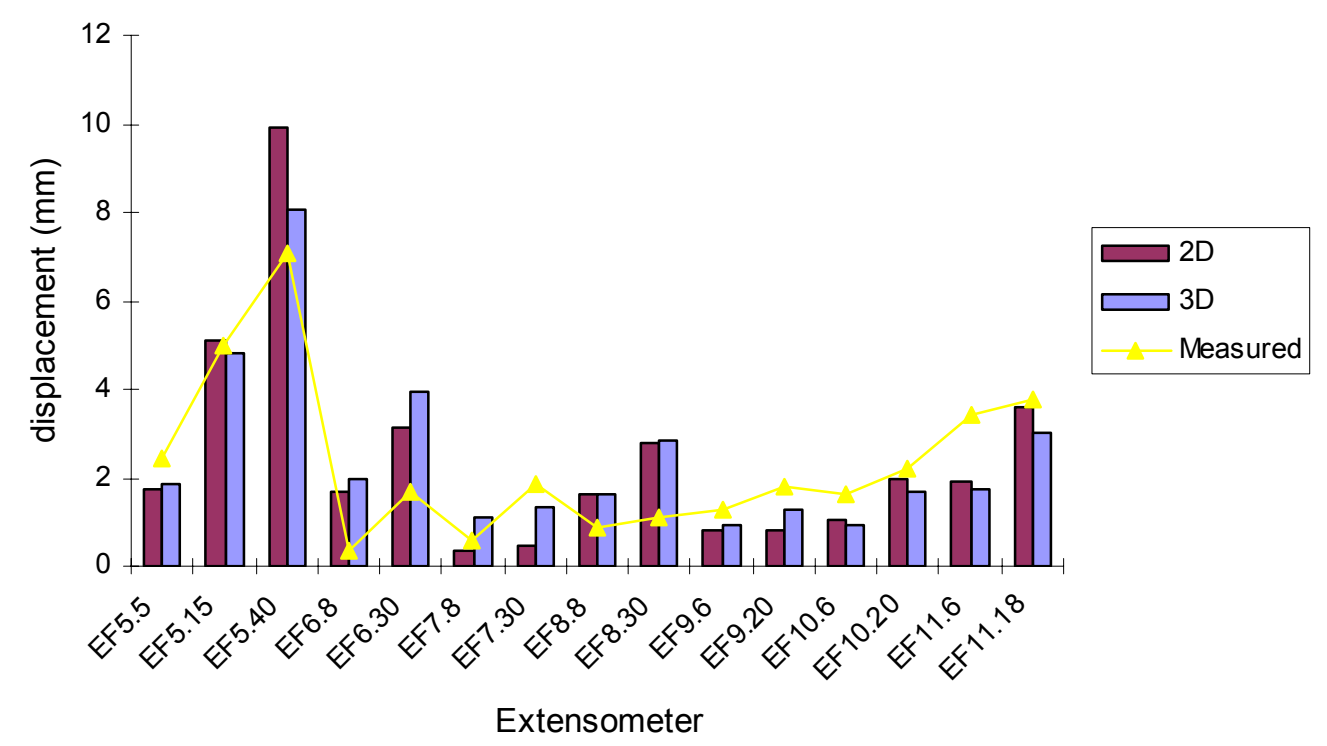

Figure 9. Comparison between computed and measured displacements

For the 3D model a calculation of the factor of safety was carried out. FLAC3D uses the method defined by Dawson et al. (1999) in which the strength parameters are consecutively reduced until significant plastic flow appears in some zone of the structure. The computed factor of safety was 4.63 which can be considered satisfactory in terms of security level. Figure 10 shows an image of the last non-equilibrium state produced by the methodology of strength reduction applied to calculate the factor of safety. The shear strain contours allow the visualization of the failure mode.

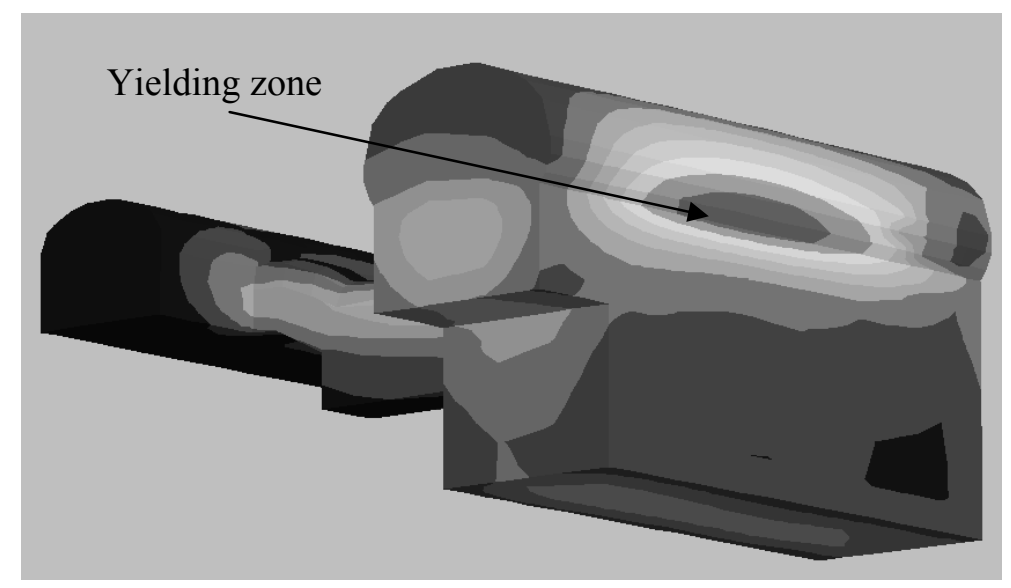

Figure 10. 3D visualization of the shear strain contours for the last non-equilibrium state

Plastic flow appears in the connection zone between the vertical wall and the beginning of the arch which is an area of stress concentration. This fact can be corroborated by the observation of Figure 10 where a cutting plane through one of the interconnecting galleries shows the shear strain contours and velocity vectors. It can be seen that potential instability zones are located near the connections between the vertical walls of the main cavern and the ceiling arch mainly near the high span vertical wall (opposite to the interconnecting galleries). 


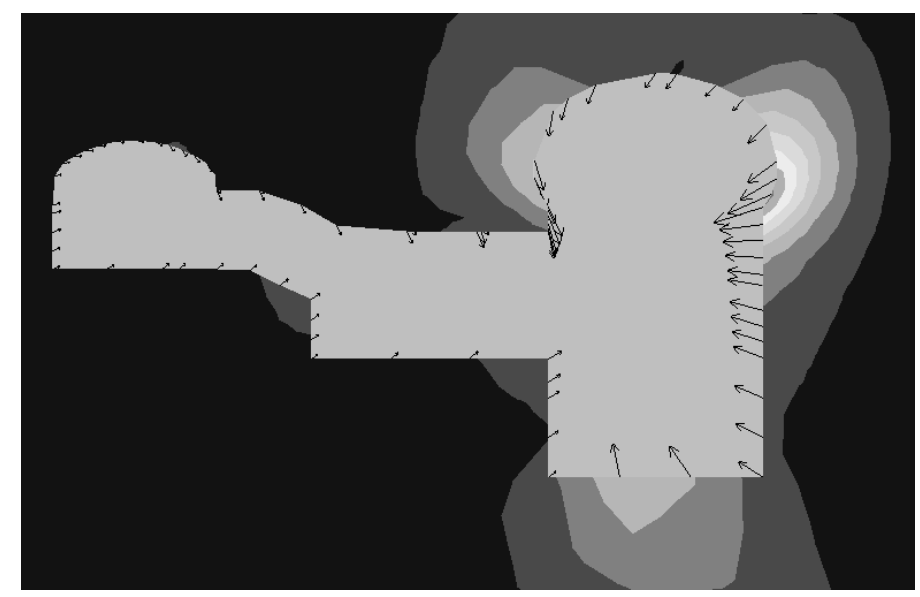

Figure 10. 2D visualization of the shear strain contours and velocity vectors

\section{CONCLUSIONS}

The Venda Nova II hydroelectric scheme built in the North of Portugal includes a set of very important underground structures. In this work 2D and 3D numerical models of the powerhouse complex were developed considering the different construction stages. The powerhouse complex is composed by two caverns connected by two galleries. Through the models their behaviour was analysed and compared with the monitored values by extensometers placed in the caverns.

The scheme is located mainly in a granite rock mass with good geomechanical characteristics as shown by the results of the geotechnical survey. The geomechanical parameters used in the models were obtained through a knowledge based system called GEOPAT. The system was developed at the University of Minho with the purpose of calculate geomechanical parameters in granite formations.

The computed displacements are small and the structure behaviour is almost elastic due to the good quality rock mass. The displacements configuration is very much influenced by the high horizontal stress perpendicular to the caverns axis. The maximum displacement values are observed near the high span vertical wall of the main cavern.

The results of the models, in a qualitative perspective, are close to the observed values. Excepting for extensometers 6 and 8, the fit can be considered acceptable for both models which present similar values. Also in a statistical point of view it is concluded that the produced results are of good quality. The mean computed displacement by the numerical models was $2.47 \mathrm{~mm}$ against the measured $2.34 \mathrm{~mm}$. The errors between measured and computed values follow a normal distribution with a mean value close to 0 which also corroborates the good quality of the fit. Concluding, in an engineering point of view, the results of the models fits very satisfactory to the observed displacements. This is especially true since the monitored displacements are very small which turns the fit more difficult to obtain (due to lack of precision in the readings, simplifications of the constructions sequence and constitutive models, etc.).

The computed factor of safety on the 3D model is 4.63 which translate an acceptable security level. The most probable failure mode taken from this calculation is plastic flow in the connection between the beginning of the arch and the vertical wall of the main cavern since its an area of stress concentration.

Backanalysis of the geomechanical parameters is being carried out using the measured and computed displacements of the 3D model. The preliminary results are presented in other work. Different techniques are being used namely the optimization software Sidolo which uses conventional search algorithms and an evolutionary algorithm. This is very innovative technique and is intended that it overcomes some limitations of conventional algorithms like the convergence to local minima. 


\section{AKNOWLEDGMENTS}

The authors wish to express their acknowledge to EDP Produção EM for authorization and making available the necessary data. This work was financed by the Foundation for Science and Technology (FCT) in the framework of the research project POCI/ECM/57495/2004, entitled Geotechnical Risk in Tunnels for High Speed Trains.

\section{REFERENCES}

Dawson, E., Roth, W., Drescher. 1999. Slope stability analysis with finite element and finite difference methods. Géotechnique 49(6), 835-840.

ISRM. 1978. Suggested methods for the quantitative description of discontinuities in rock masses. International Journal of Rock Mining Sciences \& Geomechanics Abstracts, Vol. 15, $\mathrm{n}^{\circ}$ 16, pp. 319-368.

Lima, C.; Resende, M.; Plasencia, N.; Esteves, C. 2002. Venda Nova II hydroelectric scheme powerhouse geotechnics and design. ISRM News, Vol. 7, no. 2, pp. 37-41.

LNEC. 1997. Seismic tomography between boreholes in the mass interesting the central cavern of the Venda Nova II scheme. Lisboa (in Portuguese).

Miranda, T. 2003. Contribution to the calculation of geomechanical parameters for underground structures modelling in granite formations. MCs thesis, UM, Guimarães, 186p (in Portuguese).

Plasencia, N. 2003. Underground Works - Aspects of the engineering geology contribution and design. MSc thesis, IST, Lisboa, 155p (in Portuguese).

Plasencia, N.; Coelho, M. J.; Lima, C., Fialho, L. 2000. Contribution of the seismic tomography for the characterization of the mass interesting the central cavern of the Venda Nova II scheme. $7^{\text {th }}$ Geotechnical Portuguese Congress. Porto, pp. 113-122 (in Portuguese). 